\title{
Use of Science in Collaborative Environmental Management: Evidence from Local Watershed Partnerships in the Puget Sound
}

\author{
Tomas M. Koontz ${ }^{\text {a }}$ University of Washington Tacoma \\ Craig W. Thomas ${ }^{\mathrm{b}}$, University of Washington Seattle
}

\begin{abstract}
The science-policy nexus has long puzzled scholars and managers working across diverse public policy areas, including environment. The rise of science-based management, especially in an era of big data, assumes science can improve environmental policy. At the same time, increasing attention to stakeholder engagement provides avenues for non-scientists to participate in collaborative environmental management, which might displace science in decision-making processes. Prior research points to a variety of factors thought to affect the degree to which science is used in collaborative partnerships. Drawing on such research, we examine the use of science across 9 collaborative partnerships structured and resourced from the top-down by a state government agency. All of these partnerships are working in the U.S.'s second largest estuary, the Puget Sound in Washington State. Data from partnership meeting minutes indicates that science is scarcely discussed in executive committee meetings, but is more commonly discussed in technical committee meetings. We thus might expect that the ecosystem management plans produced by these technical committees would be closely informed by science. Results indicate these plans include few citations to peer-reviewed scientific studies, but they do draw consistently on scientific information from grey literature including scientific and technical reports from federal and state agencies. These results raise important questions about government efforts to foster the use of science in collaborative partnerships, including the benefits and drawbacks of using grey literature rather than scientific articles directly, the interaction of science with other forms of knowledge, and local actors' capacity to understand and access science.
\end{abstract}

Keywords: collaborative governance; science; restoration; planning; Puget Sound Partnership

This research did not receive any specific grant from funding agencies in the public, commercial, or notfor-profit sectors.

${ }^{\text {a }}$ University of Washington Tacoma, Box 358436, 1900 Commerce St, Tacoma WA 98402 koontz31@uw.edu

${ }^{\mathrm{b}}$ University of Washington Seattle, Parrington Hall, $410015^{\text {th }}$ Ave NE, Seattle WA 98195 thomasc@uw.edu

Highlights

- We studied a "best case" with ample state assistance for partnerships to use science

- We examined the use of science in meetings and plans of 9 collaborative partnerships

- Science was scarcely discussed in executive meetings, but more in technical meetings

- Plans cited grey literature rather than scientific studies

- These results suggest the importance of science translation and informal use of science

- These results raise questions about how to bridge the science-policy divide 


\section{Introduction}

Collaborative ecosystem management should strive to use best-available science for creating and implementing plans (Layzer, 2008). Yet the extent to which science is actually used in collaborative partnerships has been little studied (Heikkila and Gerlak, 2005; Leach et al. 2013; Massaua et al. 2016). This is problematic because ecosystem-scale collaboration often includes a wide range of stakeholders, with some having little understanding of scientific methods and findings, and how best to incorporate scientific findings into planning and management activities.

In this study we examine the use of science in 9 collaborative partnerships working to improve a high-profile socio-ecological system, the Puget Sound in Washington State, the second largest estuary in the U.S. These partnerships were funded and steered by a science-based state agency that encouraged the use of science in partnership deliberations and plans. Our main research questions are as follows:

1. How much, and how, is science used in collaborative planning processes that are funded and steered by a state agency?

2. How much, and how, is science included in the plans that result from these collaborative planning processes?

We focus on collaborative partnerships that are funded and steered by a state agency on the presumption that such partnerships are more likely to incorporate science into decision-making processes than partnerships that emerge more organically from the bottom-up. Our study is thus a hard test of the use of science in collaborative partnerships, in that we expect to find it. Our results are somewhat unexpected, in that that we see scarcely any deliberation of science in executive committee meetings, and rarely are peer-reviewed scientific studies cited in the ecosystem plans. On the other hand, we do see evidence of deliberation of science in technical committees, and use of grey literature pertaining to science in the ecosystem plans.

\section{Use of Science in Collaborative Environmental Management}

Science is a process of empirical inquiry, drawing on evidence to build and test theories about phenomena of interest (King et al. 1994; Hoover and Donovan 2001; Kuhn 1962). Because many environmental issues involve complex ecological interactions, scientific knowledge is a key component in solving them. From global warming and rapid deforestation to persistent water pollution and declining ocean health, many problems call on science to inform solutions. Of course, we do not expect science to be a panacea, and complex environmental management decisions do not and should not revolve solely around science, but science can make important contributions (Ozawa 2005; Karl et al. 2007).

Collaborative partnerships are multi-stakeholder efforts that feature the communication of diverse viewpoints and generation of information for action. These partnerships are an example of a larger phenomenon known as collaborative governance, which refers to"the processes and structures of public policy decision making and management that engage people constructively across the boundaries of public agencies, levels of government, and/or the public, private, and civic spheres" (Emerson et al. 2011 p. 2). In the environmental arena, collaborative partnerships have focused on issues as diverse as watershed restoration, habitat protection, forest and range management, farmland preservation, and marine sanctuaries (Wondolleck and Yaffee 2000; Koontz et al. 2004; Thomas 2003; Curtin 2002; Weible 2008; Allen 2006; Koontz and Newig 2014).

A number of studies have suggested the importance of scientific information in fostering successful collaboration. For example, collaborative efforts to remediate acid mine drainage in West Virginia and Colorado were aided by the ability of partnerships to draw on multiple resources, including scientific and technical knowledge (Steelman and Carmin 2002). Across watershed partnerships in Washington, North Carolina, and Wisconsin, scientific information from ecological monitoring has been 
a key ingredient for generating environmental outputs such as changes in land use and increased local problem solving capacity (Born and Genskow 2000). In a review of 37 studies of collaborative watershed management, Leach and Pelkey (2001) found that partnership success was fostered by "adequate scientific and technical information" in nearly one third (11 of 37) of the studies. These studies suggest science is an important factor in successful collaborative partnerships, but they do not explain how science is actually used in planning and decision-making processes.

The idea that science is important for collaborative management success is widely shared by policy makers. Many government programs aimed at fostering collaborative environmental management provide technical assistance, data, and staff to increase the use of science in developing collaborative plans (Koontz et al. 2004). In fact, 45 states provide technical assistance to collaborative watershed groups (Hardy and Koontz 2008). For example, Ohio's Watershed Coordinator Grant program provided a free training program to interested watershed coordinators across the state (Nikolic and Koontz 2008).

The USEPA provides substantial technical guidance to help collaborative watershed partnerships interpret and use scientific data (USEPA 2009). In addition, nongovernmental organizations such as The Nature Conservancy provide collaborative groups with significant scientific and technical support (Hardy 2007; Allen 2006; Chess et al. 2000). This body of research finds that science is often supplied to collaborative partnerships, but does not explore the extent to which it is actually used.

One reason that understanding the use of science in collaborative partnerships is challenging is that it is a dynamic process. As Korfmacher and Koontz (2003) found, groups that were new to collaborative processes for farmland preservation focused on general information about public opinion, whereas groups with prior experience focused on more detailed and extensive social and spatial information relating to farmer and farmland characteristics. Research by Heikkila and Gerlak (2005) found that the role of scientific studies varies by stage in a collaborative process. Multiple scientific studies from multiple sources helped initiate collaborative efforts by raising awareness and saliency of resource management problems, but they did not lead to consensus about the causes and solutions once the partnerships moved beyond the problem identification stage (Heikkila and Gerlak 2005). These findings suggest that use of science may be more prevalent among more experienced groups and those at the plan initiation stage.

The scale and scope of a collaborative partnership also affects the use of science. Larger scale collaborations that operate at the policy level and involve substantial government engagement are more likely to use science than are smaller scale collaborations operating at the action level (Robinson et al. 2011; Margerum 2008). In fact government engagement through guidance and resources can greatly impact partnership processes and outputs (Koontz et al. 2004). We thus chose a sample of such partnerships to provide a hard test of the extent to which science is actually used in collaborative planning processes.

Scientific information is not, of course, the only valuable information in collaborative ecosystem management. Insights about time-and-place-specific phenomena, stakeholder preferences and values, political feasibility, and local institutions allow communities to understand the causes of problems and how to address them (Ostrom 1990; Wynne 1996; Fischer 2002; Wondolleck and Yaffee 2000). This blurs the distinctions between the role of scientists and non-scientists in informing collaborative management choices. In fact many authors either argue or have found that more usable knowledge can be crafted through deliberations among citizens and scientists in the local context than through traditional scientific work (Nowotny et al. 2001; Ravetz and Funtowicz 1998; Irwin and Michael 2003; Curtin 2002; Massaua et al. 2016). In practice, however, citizen-scientist interactions can be challenging because managing dialogue becomes more difficult as the number of participants grows, and as differences in vocabularies and assumptions increase. In structuring collaborative interactions, leaders sometimes divide stakeholders into workgroups to focus on different aspects of an issue (Korfmacher 1998; Curtin 2002). If scientists are partitioned into a separate workgroup, it may be difficult for scientists and nonscientists to learn from each other and integrate their efforts. In this regard, general meetings combining scientists and non-scientists for crafting a collaborative plan can help integrate science with other knowledge (Innes and Booher 2010). 
As the above studies indicate, we have some insights about the importance of using science in collaborative partnership work. Less is known about how and how much science is used in collaborative watershed planning. We investigate this phenomenon through a study of the use of science across 9 collaborative partnerships funded and steered by a state agency.

\section{Background of the Science-Collaboration Nexus in Puget Sound}

The state agency we focus on for this analysis is the Puget Sound Partnership (PSP). (The name of the agency is confusing, in that it is a state agency and not itself a voluntary collaborative partnership.) The PSP is charged with using a science-based approach to steer others' actions across multiple entities in the region, including the collaborative partnerships in our sample. As an encourager of collaboration (Koontz et al. 2004), the PSP provides grants and technical assistance to partnerships. Technical assistance includes science-based biannual reports it produces on the state of the Puget Sound. These reports have become more refined over the years to include reporting on 21 science-based "vital signs" that measure various dimensions of ecosystem health. The pressures affecting each vital sign, and the variables affecting these pressures, are organized into cause-effect conceptual diagrams called "results chains." The vital signs and results chains are the basis for the PSP's Puget Sound Action Agenda, a plan for making progress towards stated goals for vital signs. The Action Agenda is updated every two years to provide guidance to public agencies and collaborative partnerships for recovery of the Puget Sound ecosystem.

To encourage others to undertake restoration actions, the PSP draws on the expertise, data, and funding of state and federal agencies such as the Washington Department of Fish and Wildlife, U.S. Environmental Protection Agency, U.S. Fish and Wildlife Service, National Marine Fisheries Service, and National Oceanic and Atmospheric Administration. The PSP expends considerable effort to interact with local stakeholders, including establishing six staff positions, called Ecosystem Recovery Coordinators, to work with local communities to implement the Puget Sound Action Agenda. The PSP has also created and funded nine Local Integrating Organizations (LIOs), which are the collaborative partnerships in our empirical analysis below.

The PSP established these LIOs in 2010 for five purposes: (1) advise the PSP on local priorities in the Action Agenda, (2) provide assistance to enhance implementation of work by local groups; (3) work cooperatively to implement strategic actions by the Action Agenda; (4) base work on the best scientific information available, including information from tribal, local, state, federal, and Puget Sound Partnerships' scientific staff and the science panel [bold type not in original]; and (5) evaluate progress implementing the Action Agenda at the local scale. The PSP provides grants to the LIOs to support staff, and in return LIOs provide reports and plans in support of the Action Agenda. The LIOs received $\$ 175,000$ each to prepare science-based Ecosystem Recovery Plans.

While LIOs vary in structure, each includes an executive committee comprised of local government and tribal leaders. For example, the executive committee of the Alliance for a Healthy South Sound LIO includes four country government elected officials (one per county in the watershed) and three tribal representatives, while the Island LIO executive committee includes three county commissioners, two port district commissioners, three city mayors, and one tribal cooperative representative. In addition, many LIOs have developed technical committees to assist in their work. These technical committees typically include a broad range of organizational representatives. For example, the technical committee of the San Juan LIO is comprised of 13 members, including heads of county planning, public health, environmental health agencies; and representatives of the town of Friday Harbor, salmon recovery lead entity, marine resources committee (two members); water resources committee, economic development council, conservation district, tribes, and Friday Harbor Laboratories (a University of Washington marine lab). Our study focuses specifically on the extent to which science is used in technical versus executive committee meetings, as well as in ecosystem management plans.

A focal point for many collaborative watershed partnerships is the creation of an ecosystem management plan (e.g., Koontz and Newig 2014; Moore and Koontz 2003). For the LIO partnerships, the 
PSP requires that each LIO develop a local 5-year Ecosystem Recovery Plan, which must include at least four PSP vital signs to focus on (Puget Sound Partnership, n.d., 2016 Action Agenda Update: LIO Planning). The plans must include a text narrative and a graphical results chain showing how particular actions are expected to generate particular changes in conditions that will lead to changes in particular vital signs. In addition, each LIO is tasked with developing descriptions of "near term actions" (NTAs) to be accomplished within the next two years to implement the 5-year plans.

Although the 5-year plans and near-term actions were generated by LIOs, the process was quite top-down. The PSP provided specific deadlines, requirements, and formats for all of the deliverables. Moreover, LIO representatives were required to meet with PSP staff in person to present their deliverables. Some of their detailed requirements relate to the use of science. One guidance document instructed LIOs to "Briefly discuss the information considered when selecting ecosystem and human wellbeing priorities and Vital Signs, as outlined in Vital Sign Selection Aug 24, 2015. Include a table summarizing the information used in this selection process" (2 Sept $30^{\text {th }}$ Full Package Guidance 2015-0826, p. 2). A parallel guideline directs LIOs to discuss information considered when selecting priority pressures (e.g., the causes of impairments to the Puget Sound).

The PSP guidance states that the recommended actions in LIO plans should be based on information from "experts including natural scientists, engineers, economists and other social scientists, or other knowledgeable individuals both inside and outside the LIO working group. In some settings, information sources will also include local resource users. .." (p. 19). The guidance further recommends that "the mechanisms, supporting or dissenting studies, provenance, and expertise underlying predicted impacts should all be presented, explained, discussed, and even questioned and defended in the context of LIO deliberations" [bold type not in original] (p. 20). Without mentioning science explicitly, this text is an apt description of the scientific process, including consideration of studies and description of mechanisms posited to link strategies to pressures to outcomes. Note that this process is to include presenting, explaining, discussing, and questioning such studies and mechanisms. Thus LIO deliberations should include science, both at the technical and executive levels.

\section{Methods}

Data to answer our research questions come from analyzing two types of documents: meeting minutes and ecosystem management plans. First, we analyzed meeting minutes from all LIO executive and technical committees that were published on the internet between January 2014 and October 2015. This time frame corresponded with work on the ecosystem recovery plans. We found meeting minutes for 8 LIO executive committees (one of the 9 LIOs did not publish its meeting minutes) and 3 LIO technical committees. In total we collected 36 executive committee minutes from the $8 \mathrm{LIOs,}$ and 12 technical committee meeting minutes from 3 LIOs. Unfortunately verbatim transcripts were not available, so we don't have a word-for-word record of discussions. But meeting minutes identified items that were discussed, often labeled "Discussion." These typically listed the person who led such discussion and what additional points about it were raised at the meeting. Thus rather than analyze specific utterances, our analysis focuses more broadly on topics that came up during the meeting, as reported in the meeting minutes.

The second type of document we analyzed was ecosystem management plans. Specifically, we analyzed all 9 of the draft LIO Ecosystem Recovery Plans submitted to the PSP in October 2015. These plans represented all 8 LIOs for which we analyzed meeting minutes, plus one additional LIO which did not publish minutes.

Our aim with these cases is not to generalize to all partnerships, but rather to examine the use of science across partnerships that were strongly encouraged to use science by a lead government agency. Given the significant levels of technical assistance, policy guidelines, and funding emanating from the PSP, these partnerships provide a "most likely" case for the use of science in collaborative partnerships. Put differently, if we do not find much use of science in these partnerships, then we should expect even 
less use of science by other collaboratives. Given the popularity of government programs to encourage collaborative partnerships to use science in planning, results from these cases should also provide insights for policy makers in other contexts.

\subsection{Coding Meeting Minutes for the Executive and Technical Committees}

We first developed an initial set of codes for common topics likely to come up in collaborative partnership meetings, such as reports of on-the-ground projects completed or being completed, and discussions about future projects, developing ecosystem management plans, strategies for organizing and funding the partnership, and conducting outreach to share information with community partners or the public. We also defined a code "use of science" to be broadly inclusive of the following items: consulting with scientists as a basis for recommendations, reporting that others are compiling factors affecting an environmental outcome, discussing results of scientific research, and compiling research on restoration efforts. We sought to cast a broad net with this "use of science" code, since we did not know a priori whether and how science was discussed in these meetings.

A coding team of four students began the coding process by analyzing three executive meeting minutes each and then discussing their work with the rest of the team. Following Campbell et al. (2013), each coder identified distinct blocks of text representing "meaning units" related to the codes. For example, if someone reported during a meeting that a partnership booth was staffed at two community events, this text block would be grouped together as one "meaning unit" using the code "outreach," regardless of whether it was reported in the minutes in one short sentence or two full paragraphs (Garrison et al. 2006). This method of unitization provides a consistent method across meetings to describe the breadth and frequency of different topics expressed in meetings. It avoids inconsistencies from different levels of detail recorded by different note takers, because all of a discussion on a particular topic is coded as one text block, regardless of the level of detail. In other words, more detailed notes do not count as more text blocks than less detailed notes.

Discussions among coders during the coding process promoted clarification of definitions and common understanding of the codes. Each meeting minutes document was coded by at least one student (two students for executive committee meeting minutes, one student for technical committee meeting minutes), and then the lead author analyzed every instance where at least one student coded a block as "use of science" to corroborate the code.

\subsection{Coding LIO Ecosystem Recovery Plans}

While meeting minutes provide evidence of the use of science during decision-making processes, we are also interested in the use of science in collaborative outputs. A key output for collaborative partnerships is a management plan to describe goals, assess current trends, and suggest priorities for actions. Here we are interested in the degree to which these plans exhibit use of science. Following Koontz (2003) and Desmaris and Hird (2013), we analyzed the plans for basic features such as page length and number of PSP vital signs included, as well as our primary interest in the use of science as indicated by number of citations to different sources, including peer reviewed, scientific journal publications and grey literature (reports and studies published outside traditional peer-reviewed scientific journals or books). This coding for "use of science" in the plans follows Desmarais and Hird (2013), who examined how scientific research is incorporated into Regulatory Impact Analyses (RIAs) in U.S. federal agencies. They operationalized "use of science" as the number and type of references present in RIA documents. They found that most citations were not to peer-reviewed scientific journals, but rather to grey literature including think tank reports, government reports, and newspapers.

In our plan coding we distinguish between scientific information published in peer-reviewed scientific journals and in grey literature. For the latter, we include reports and documents with ecological data and analysis to describe phenomena (e.g., salmon population numbers over time) or cause-effect relationships (e.g., factors contributing to water pollution in a particular stream). This information is 
typically used to address a specific problem in a particular context, with the aim to inform management choices rather than to produce generalizable knowledge. Grey literature may be published with or without peer review, typically from a government agency or think tank.

\section{Results}

\subsection{Use of Science in Executive Committee Meetings}

Executive Committee meetings are the forums where general activities of partnerships are discussed. These meetings are held not only for the executive committee members, but to communicate the work of the partnership to a diverse array of interested parties, and to hear reports from technical committees. For the LIO partnerships, meeting minutes indicate that attendance typically included 12-20 people, comprised of both executive committee members and others.

Overall, executive committee meetings included very little use of science. Across 36 coded executive committee meetings, coders counted just 19 instances of the use of science out of 277 text blocks, representing $6.9 \%$ of all text blocks (see Table 1). Far more common were themes related to plans in process, plans completed, and funding sources.

Table 1 Use of Science in Executive Committee Deliberations, Meeting Minutes

\begin{tabular}{|l|l|l|l|}
\hline Partnership & $\begin{array}{l}\text { Number of text } \\
\text { blocks }\end{array}$ & $\begin{array}{l}\text { Number of text } \\
\text { blocks with Use } \\
\text { of Science }\end{array}$ & $\begin{array}{l}\text { Percent of text blocks with } \\
\text { Use of Science }\end{array}$ \\
\hline LIO1 & 95 & 7 & $7.4 \%$ \\
\hline LIO2 & 4 & 0 & $0 \%$ \\
\hline LIO3 & 18 & 1 & $5.6 \%$ \\
\hline LIO4 & 14 & 2 & $14.3 \%$ \\
\hline LIO5 & 53 & 3 & $5.7 \%$ \\
\hline LIO6 & 38 & 0 & $0 \%$ \\
\hline LIO7 & 4 & 1 & $25 \%$ \\
\hline LIO8 & 51 & 5 & $9.8 \%$ \\
\hline TOTAL & $\mathbf{2 7 7}$ & $\mathbf{1 9}$ & $\mathbf{6 . 9 \%}$ \\
\hline
\end{tabular}

$\mathrm{N}=36$ meetings

We coded several ways in which science can be used, including themes of consulting with scientists as a basis for recommendations, reporting that others are compiling factors affecting an environmental outcome, discussing results of scientific research, and compiling research on restoration efforts. Examples of each of these themes are shown in Table 2.

Table 2 How Science is Used in Executive Committee Meeting Minutes

\begin{tabular}{|l|l|}
\hline Theme & Example \\
\hline $\begin{array}{l}\text { Consulting with scientists } \\
\text { as a basis for } \\
\text { recommendations }\end{array}$ & $\begin{array}{l}\text { At one meeting the discussion turned to the topic of funding allocation to } \\
\text { salmon projects. The minutes recorded that "He [a partnership member] is } \\
\text { worried about the science. He alone can't do the buy-off [approval], which } \\
\text { is why he consults with scientists making recommendations and not } \\
\text { politicians." }\end{array}$ \\
\hline $\begin{array}{l}\text { Reporting that others are } \\
\text { compiling factors } \\
\text { affecting an }\end{array}$ & $\begin{array}{l}\text { At one meeting, participants discussed the process of developing a list of } \\
\text { priorities for salmon recovery efforts. It was noted that the first step in } \\
\text { identifying prioritization process involves a contractor gathering information }\end{array}$ \\
\hline
\end{tabular}




\begin{tabular}{|l|l|}
\hline environmental outcome & $\begin{array}{l}\text { about cause-effect relationships: "Biostream Environmental is the contractor. } \\
\text {. step 1 is to issue synthesis of the information that is available on the } \\
\text { factors that keep many salmonid stocks at current performance." }\end{array}$ \\
\hline $\begin{array}{l}\text { Discussing results of } \\
\text { scientific research }\end{array}$ & $\begin{array}{l}\text { At one meeting the group discussed scientific research to measure } \\
\text { contaminant levels in the water: "Chris discussed marine mammal surveys. } \\
\text { The Nisqually [River] has long been the baseline for analyzing Puget Sound } \\
\text { contaminates studies, sacrificing some Chinook [salmon] to analyze local } \\
\text { contaminates. Some examples include cocaine, nicotine, and more." }\end{array}$ \\
\hline $\begin{array}{l}\text { Compiling research on } \\
\text { restoration efforts }\end{array}$ & $\begin{array}{l}\text { At one meeting, a member reported interacting with people outside the LIO } \\
\text { to gather research about ecological restoration: "She also met with folks } \\
\text { from the NNWR to brainstorm ways to compile research regarding the delta } \\
\text { restoration efforts." }\end{array}$ \\
\hline
\end{tabular}

\subsection{Use of Science in Technical Committee Meetings}

Technical Committee meetings are the forum where experts, including scientists, meet to discuss more technical aspects of plans and projects. Although meeting minutes are scarcer than for executive committee meetings, those that are available indicate a more extensive use of science (as expected) compared to executive committee meetings.

The LIO technical committees sometimes centered entire meetings around science-related questions, and they delved into how to evaluate cause-effect relationships in socio-ecological systems, how to aggregate results of such evaluations across different regions, how to incorporate social science into communications, and how to make effective use of citizen science. These committees discussed things like organizing a local science seminar, prioritizing projects to monitor and use scientific data, and comparing local scientific knowledge to make "results chains" (cause-effect diagrams) required by PSP more relevant to the local context. Many of these discussions surrounded two main tasks: prioritizing Near Term Actions and drafting the Ecosystem Recovery Plan, both of which involved explaining causal links among variables. These themes represented much more engagement in science than the typical themes from executive committee meetings. To the extent executive committee meeting minutes noted science, it mostly involved reporting about others doing science (recall Table 2). By contrast, across the 12 coded LIO technical meetings, we counted 37 instances of the use of science, including one meeting that included extensive discussions (and an attached Powerpoint presentation) focusing on cause-effect relationships and scientific understanding of impediments to watershed health (see Table 3 ).

Table 3 How Science is Used in Technical Committee Meeting Minutes

\begin{tabular}{|l|l|l|l|}
\hline Partnership & $\begin{array}{l}\text { Number of } \\
\text { Text blocks } \\
\text { with Use of } \\
\text { Science }\end{array}$ & Themes & Examples \\
\hline $\begin{array}{l}\text { LIO7 (7 } \\
\text { meetings) }\end{array}$ & 5 & $\begin{array}{l}\text { Discussing cause- } \\
\text { effect relationships; } \\
\text { discussing how to } \\
\text { amend PSP results } \\
\text { chains }\end{array}$ & $\begin{array}{l}\text { Minutes noted that a member said Near Term } \\
\text { Actions should include adapting to new } \\
\text { science. Members discussed the following: } \\
\text { cause-effect relationships in results chain; how } \\
\text { the PSP priority pressures for the region did not } \\
\text { match local experts' view of priority pressures } \\
\text { and supporting evidence; how results chain } \\
\text { from PSP did not include international } \\
\text { pressures from Canada that cause }\end{array}$ \\
\hline
\end{tabular}




\begin{tabular}{|l|l|l|l|}
\hline & & & $\begin{array}{l}\text { environmental harm. One meeting noted that } \\
\text { there was a presentation of conceptual models } \\
\text { and results chain for Chinook salmon. }\end{array}$ \\
\hline $\begin{array}{l}\text { LIO4 (4 } \\
\text { meetings) }\end{array}$ & 6 & $\begin{array}{l}\text { Discussing results } \\
\text { chains and } \\
\text { generalizing to other } \\
\text { regions; basing } \\
\text { strategies on social } \\
\text { science; discussing } \\
\text { citizen science best } \\
\text { practices; planning } \\
\text { local science } \\
\text { seminars to share } \\
\text { science with the } \\
\text { public }\end{array}$ & $\begin{array}{l}\text { Minutes reported that the group held a local } \\
\text { science seminar to inform NTA prioritization. } \\
\text { Meetings featured apresentation and discussion } \\
\text { about evaluating results chains and } \\
\text { generalizing results through meta-analysis to } \\
\text { other regions in the Puget Sound. A member } \\
\text { noted that social science is needed to better } \\
\text { communicate science to non-scientific } \\
\text { audiences. There was adiscussion of how to } \\
\text { effectively use citizen scientists. There was } \\
\text { adebriefing about local science seminar and } \\
\text { plans for next year }\end{array}$ \\
\hline $\begin{array}{l}\text { Liscussing cause- } \\
\text { meeting; } \\
\text { minutes with } \\
\text { associated } \\
\begin{array}{l}\text { Powerpoint } \\
\text { slides) }\end{array}\end{array}$ & 25 & $\begin{array}{l}\text { This was a 3-hour meeting to review and rank } \\
\text { Near Term Actions, including monitoring for } \\
\text { scientific data and studies to better understand } \\
\text { cause-effect relationships }\end{array}$ \\
\hline
\end{tabular}

$\mathrm{N}=12$ meetings

In sum, our analysis of meeting minutes suggests that executive committee meetings rarely included discussions of science. When science was mentioned in executive meeting minutes, the discussions centered on reporting that others are compiling research or consulting with scientists, with some talk about the results of scientific research. Technical committee minutes, not surprisingly, included more extensive use of science and deeper discussion about aspects of science, including weighing the evidence for particular cause-effect relationships, best practices for citizen science and their appropriateness for scientific questions, and inclusion of social science. This analysis of meeting minutes shows us how science is discussed during the collaborative process in different types of committees. To understand the use of science in the collaborative outputs that subsequently emerge, we turn to analysis of the use of science in the LIO ecosystem management plans.

\subsection{Use of Science in Ecosystem Management Plans}

The 9 LIO Ecosystem Recovery Plan drafts closely follow a format prescribed by the PSP. Each includes the same sections, in the same order, but the contents vary based on which PSP vital signs were chosen for inclusion. Plan lengths ranged from 24 to 87 pages, and each plan included 4 to 14 PSP vital signs and described how these vital signs are locally relevant and can be implemented (see Table 4).

Table 4: Ecosystem Management Plan Characteristics

\begin{tabular}{|l|l|l|l|l|}
\hline & $\begin{array}{l}\text { Number of priority } \\
\text { vital signs }\end{array}$ & $\begin{array}{l}\text { Pages of } \\
\text { plan }^{\mathrm{a}}\end{array}$ & $\begin{array}{l}\text { Listed Sources of } \\
\text { Information }\end{array}$ & $\begin{array}{l}\text { Peer Reviewed } \\
\text { Scientific journals }\end{array}$ \\
\hline LIO1 & 6 & 24 & 6 & 0 \\
\hline LIO2 & 6 & 47 & 3 & 0 \\
\hline LIO3 & 8 & 50 & 2 & 0 \\
\hline LIO4 & 6 & 47 & 2 & 0 \\
\hline
\end{tabular}




\begin{tabular}{|l|l|l|l|l|}
\hline & & & & \\
\hline LIO5 & 11 & 63 & 5 & 0 \\
\hline LIO6 & 14 & 61 & 2 & 0 \\
\hline LIO7 & 6 & 42 & 8 & 0 \\
\hline LIO8 & 4 & 54 & 5 & 1 \\
\hline LIO9 & 6 & 87 & 8 & (1 conference paper) \\
\hline
\end{tabular}

a single spaced including all tables and appendices

Across all 9 LIO plans, direct references to peer-reviewed scientific journal articles are nonexistent in the text. No plans used in-text references to support particular claims; rather, a summary table of the sources of information used for different plan components was provided. These summary tables indicated the most common documents the planners referenced were grey literature including PSP documents and other plans developed by the LIO, such as the PSP 2014 Action Agenda (a leadership and coordinating document), Chinook Monitoring and Adaptive Management reports (local analyses describing science-based adaptive management), PSP 2014 Puget Sound Pressure Assessment (a technical report), and each LIO's 2014 Near Term Actions document (local analyses describing causes of impairment and prioritizing actions for ecosystem restoration). Just one citation to a peer-reviewed scientific journal article was found across the 9 plans. Our subsequent analysis of these grey literature sources found that they included some citations to peer-reviewed journal articles, but most of their citations are to science-based grey literature. Hence, it is clear from the citation trail that the LIO plans were science-based, but not based directly on peer-reviewed journal articles. Interestingly, the 2014 Puget Sound Pressure Assessment (a technical report) was created through contributions from 60 experts (many of whom were scientists) selected by the PSP Science Panel who provided their expertise on stressor-endpoint relationships. Since it was an expert elicitation, it represents tapping into scientific knowledge through the experts rather than citing peer-reviewed articles directly.

\section{Discussion}

Prior studies of the use of science in collaborative partnerships suggest we should see a substantial use of science in the nine partnerships we studied (Massaua et al. 2016; Robinson et al. 2011; Koontz et al. 2004). After all, the core mission of the state agency (PSP) includes a science-based approach to ecosystem recovery. Moreover, the PSP shared funding, technical assistance, and staffing resources with the LIOs; and LIO participants included those with scientific expertise. Yet, our measures of the use of science suggest that science was rarely discussed in executive committee meetings. In contrast, technical committees more deeply discussed science in their meetings, as expected. Yet the products of these meetings (i.e., the ecosystem recovery plan drafts) included few references to peer-reviewed scientific journals, relying instead on indirect citations to science-based grey literature.

The PSP's efforts to infuse science and scientific reasoning throughout the LIOs have thus not been fully realized, at least with respect to decision-making processes within executive committees and the contents of draft plans. However, it could be argued that executive committees are not the most appropriate place to focus on science. The executive committee meetings we analyzed were occupied primarily with organizing tasks, discussing budgets, maintaining the organization, and bringing information to the group about what other organizations are doing in their field. Scientific discussions and deliberation might be more appropriately located in the technical committees. Yet, in order to incorporate science into the collaborative plans, which involve participants beyond the technical committees, the executive committees need to include science along with their focus on budgets, politics, feasibility, task organization, etc.. 
Moreover, our analysis of ecosystem management plans shows that science from peer-reviewed journals is not directly cited in LIO plans, but the plans do incorporate information from PSP and other documents that are grounded in peer-reviewed science. This is in line with findings from Desmarais and Hird (2013), who found that federal agencies more often cited grey literature, including government reports, than peer-reviewed scientific journals. Since peer-reviewed scientific journals can be difficult for non-scientists to comprehend, the use of grey literature that draws on science may be more effective for a plan whose intended audience includes non-scientists.

Another channel through which science may be transmitted, in addition to grey literature, is through discussions with scientists. The technical committee meetings, which included experts who were scientists, did include deliberations about scientific questions and the use of science. In addition, one of the documents frequently cited in the LIO plans was the 2014 Puget Sound Pressure Assessment, which was an expert elicitation study. Thus, scientific information was embodied in the experts who contributed to the study, rather than in scientific paper citations. Such use of science via discussions has been highlighted in studies of conflict resolution, where disagreeing stakeholders are brought together by a mediator to find common ground. Scholars have identified the benefits of joint fact finding, where nonscientists interact with scientists to develop data, forecasts, assumptions, and even model parameters (Ozawa 2005). This kind of discussion was listed by the PSP in its guidance for LIO planning, but it did not often occur in executive committee meetings.

\section{Conclusion}

Collaborative ecosystem management efforts often call for the use of science in developing plans to address environmental problems, and substantial funding has been invested for large-scale ecosystem management agencies such as the Puget Sound Partnership. The PSP is a leader in bringing both natural and social science to bear on ecosystem management, including building cause-effect results chains based in scientific evidence. But collaborative efforts, by definition, cannot be solely top-down, governmentdriven efforts. They need participation from stakeholders at the local level, even though scientific capacity at the local level may be lacking. Public agencies such as the PSP strive to engage with local actors in developing Ecosystem Recovery Plans based in science and built on the PSP-generated causeeffect results chains. Thus, rather than relying on local ideas bubbling up to the PSP, the PSP actively guides and funds Local Integrating Organizations (LIOs) to develop plans following a prescribed format that includes results chain, indicators, and sources of evidence. This is a double-edged sword, as strong top-down guidance may encourage the use of science yet also reduce the possibility of creative, novel approaches from the local level (see Bidwell and Ryan 2006). It can also create challenges for LIOs who value the funding but may see their own priorities and cause-effect relationships as not fully matching those of the PSP.

Across our study cases, science was rarely brought up in executive committee meetings, but had a greater presence in technical committee meetings. In the latter, substantial deliberation occurred over research questions, data, usability of findings, and communicating science with non-scientists. Despite the clear use of science within technical committees, the ecosystem management plans they produced include few citations to peer-reviewed scientific studies. The LIO plans do, however, draw on scientific information from grey literature, including scientific and technical reports from federal and state agencies. Moreover, a frequently used source of information in LIO plans was a PSP document based on expert elicitation, which provided access to scientific information through people rather than scientific papers, suggesting that the use of science occurs through informal channels, which cannot be measured in formal plans.

Results raise an important question about the way science is used in collaborative plans whose writers and audiences include non-scientists. The prevalence of grey literature suggests a kind of translation is taking place, from peer-reviewed journal articles to science-informed reports, that may be more readily understood and acted upon by managers and local stakeholders. Is this an effective means to convey science and put it into practice, or is something lost in translation? What are the benefits and 
drawbacks of relying on grey literature rather than scientific articles directly for collaborative ecosystem management plans?

Once the degree to which, and the way, science is used is more fully understood, we can ask related questions about the use of science versus the use of other forms of knowledge. In particular, ecosystem planning and management is subject to not only scientific knowledge, but also local knowledge and, when government agencies are engaged, managerial knowledge. These three types of knowledge are not mutually exclusive, as local knowledge is often viewed as being traditional ecological knowledge or local time-and-place knowledge, yet local actors may also generate scientific knowledge. In addition, while managerial knowledge is often viewed as knowledge about bureaucratic processes, it can also overlap with scientific knowledge, as Fleischman and Briske (2016) have termed "professional ecological knowledge." How these forms of knowledge interact, and which forms of knowledge are most impactful on which aspects of watershed management, remains an open question.

Of particular interest to practitioners is the question of how to encourage the appropriate use of science in solving complex socio-ecological problems. The PSP is a good example of a public agency that is spending substantial time, money, and effort to encourage science-based planning and action within local collaborative partnerships. To the extent that locally-based use of science is helpful in solving problems, it is important to identify barriers to the use of science, and strategies to overcome those barriers. For example, do local actors know how to approach a question scientifically? Do they understand which questions are amenable to scientific information? Do they have access to understandable scientific knowledge that is outside their area of expertise and may be in subscriptionbased scientific journals? Do scientists take into account the information needs of managers when conducting research? What affects the degree to which academic journals seek to publish actionable research with implications for managers? What might be the role of translators who can understand science and communicate it effectively to non-scientists? And what might be the role of government in fostering increased use of science?

This preliminary investigation raises more questions than it answers. Our data analysis captures part of the story, but more detailed understanding can be gained from interviews, surveys, and observations. Researchers should therefore supplement coding of formal documents with interviews that provide more context about how science is discussed and applied in practice. This should include discussions about science that occur outside formal meetings. For example, interviews could ask participants to discuss how and why they used science in decision making and planning processes. A survey could collect quantitative data about prevalence of different kinds of science and factors affecting its use. Observations at meetings could provide verbatim transcripts for discourse analysis.

Answering such questions will require sustained efforts by political scientists and other social scientists. Fortunately, there is no lack of empirical cases from which to draw, as policy makers increasingly seek to address complex socio-ecological problems that involve scientists and a wide range of stakeholders.

\section{Acknowledgements}

The authors thank members of the research team who collected and analyzed meeting minutes: Rachel Sangsland, Calum Ramsay, Dez Overman, and Elisha Gentry.

\section{REFERENCES}

Allen, Larry S. 2006. "Collaboration in the borderlands: The Malpai Borderlands Group." Rangelands 28(3): 17-21.

Bidwell Bidwell, R.D., and C.M. Ryan. 2006. Collaborative Partnership Design: The Implications of Organizational Affiliation for Watershed Partnerships. Society and Natural Resources 19(9) 827842. 
Born, Stephen M. and Kenneth D. Genskow. 2000. The watershed approach: An empirical assessment of innovation in environmental management. National Academy of Public Administration, Washington, DC, Research Paper Number 7. http://www.napawash.org/pc_economy_environment/epafile0701.pdf accessed 7/27/2009.

Campbell, John L., Charles Quincy, Jordan Osserman, and Ove K. Pedersen. 2013. "Coding In-depth Semistructured Interviews: Problems of Unitization and Intercoder Reliability and Agreement." Sociological Methods and Research 42(3):294-320.

Chess, Caron, Billie Jo Hance, and Ginger Gibson. 2000. "Adaptive participation in watershed management." Journal of Soil and Water Conservation Third Quarter: 248-252.

Curtin, Charles G. 2002. Integration of science and community-based conservation in the Mexico/U.S. Borderlands. Conservation Biology 16(4): 880-886.

Desmarais, Bruce A., and John A. Hird. "Public policy's bibliography: The use of research in US regulatory impact analyses." Regulation \& Governance 8.4 (2014): 497-510.

Fischer, F., 2002. Citizens, experts and the environment. Duke University Press, Durham.

Fleischman, F., and D. D. Briske. 2016. Professional ecological knowledge: an unrecognized knowledge domain within natural resource management. Ecology and Society 21(1):32. http://dx.doi.org/10.5751/ES-08274-210132

Garrison, D. R.,M. Cleveland-Innes, Marguerite Koole, and James Kappelman. 2006. " Revisiting Methodological Issues in Transcript Analysis: Negotiated Coding and Reliability." Internet and Higher Education 9:1-8.

Hardy, Scott. 2007. Not so eerie anymore? The promise of collaborative watershed management in the Lake Erie Basin. Unpublished doctoral dissertation. The Ohio State University School of Environment and Natural Resources.

Hardy, Scott D. and Tomas M. Koontz. 2008. "Reducing nonpoint source pollution through collaboration: Policies and programs across the U.S. states." Environmental Management 41(3):301-310.

Heikkila, Tanya, and Andrea K. Gerlak. 2005. "The formation of large-scale collaborative resource management institutions: Clarifying the roles of stakeholders, science, and institutions." The Policy Studies Journal 33(4):583-612.

Hoover, Kenneth, and Todd Donovan. 2001. The elements of social scientific thinking 7 th ed. New York: St Martin's Press.

Innes, Judith and David Booher. 2010. Planning with Complexity: An introduction to collaborative rationality for public policy. Routledge

Irwin, A., and M. Michael. 2003. Science, social theory and public knowledge. Maidenhead: Open University Press.

Karl, H. A., Susskind, L. E., \& Wallace, K. H. (2007). A dialogue, not a diatribe: effective integration of science and policy through joint fact finding. Environment: Science and Policy for Sustainable Development, 49(1), 20-34.

King, Gary, Robert Keohane, and Sidney Verba. 1994. Designing social inquiry. Princeton: Princeton University Press.

Koontz, Tomas M. 2003. "The Farmer, the Planner, and the Local Citizen in the Dell: How Collaborative Groups Plan for Farmland Preservation." Landscape and Urban Planning 66(1): 19-34.

Koontz, Tomas M., and Jens Newig. 2014. "From Planning to Implementation: Top Down and Bottom Up Approaches for Collaborative Watershed Management.” Policy Studies Journal 42(3):416442.

Koontz, Tomas M., Toddi A. Steelman, JoAnn Carmin, Katrina Smith Korfmacher, Cassandra Moseley, and Craig W. Thomas. 2004. Collaborative environmental management: What roles for government? Washington, D.C: Resources for the Future Press. 
Koontz, Tomas and Craig Thomas. 2017. "The Science-Policy Nexus in Collaborative Governance: Knowledge Use in Ecosystem Recovery Efforts." Paper presented at the Midwest Political Science Association annual meeting, April 6-9, Chicago.

Korfmacher, Katrina. 1998. "Invisible successes, visible failures: Paradoxes of ecosystem management in the Albemarle-Pamlico Estuarine Study." Coastal Management 26(3): 191-212.

Korfmacher, Katrina Smith, and Tomas M. Koontz. 2003. "Collaboration, information, and preservation: The role of expertise in farmland preservation task forces." Policy Sciences 36: 213-236.

Layzer, Judith A. 2008. Natural experiments: Ecosystem-based management and the environment. Cambridge: MIT Press.

Leach, William D., Neil W. Pelkey, and Paul A. Sabatier. 2002. "Stakeholder partnerships as collaborative policymaking: Evaluation criteria applied to watershed management in California and Washington." Journal of Policy Analysis and Management 21(4): 645-670.

Leach, William D. and Neil W. Pelkey, 2001. "Making watershed partnerships work: A review of the empirical literature." Journal of Water Resources Planning and Management, 127(6): 378-385.

Leach, William D., et al. "Fostering learning through collaboration: Knowledge acquisition and belief change in marine aquaculture partnerships." Journal of Public Administration Research and Theory (2013): mut011.

Margerum, Richard D. 2008. "A typology of collaboration efforts in environmental management." Environmental Management 41:487-500.

Massaua, Meghan, Craig Thomas and Terrie Klinger. 2016. "The use of science in collaborative management of marine environments." Coastal Management 44: 606-627.

Moore, Elizabeth A., and Tomas M. Koontz. 2003. "A Typology of Collaborative Watershed Groups: Citizen-based, Agency-based, and Mixed Partnerships." Society and Natural Resources 16(5):451-460.

Nikolic, Sara, and Tomas M. Koontz. 2008. "Nonprofit Organizations in Environmental Management: A Comparative Analysis of Government Impacts." Journal of Public Administration Research and Theory 18:441-463.

Nowotny, H., P. Scott, and M. Gibbons. 2001. Re-thinking science. Knowledge and the public in an age of uncertainty. Cambridge: Polity Press.

Ostrom, Elinor. 1990. Governing the commons: The evolution of institutions for collective action. Cambridge: Cambridge University Press.

Ozawa, C. (2005). Putting science in its place. In J. T. Scholz \& B. Stiftel (Eds.), Adaptive governance and water conflict. New institutions for collaborative planning (pp. 185-195). Washington, DC: Resources for the Future.

Puget Sound Partnership, no date, Action Agenda Overview, http://psp.wa.gov/action agenda center.php, accessed March 8, 2016

Puget Sound Partnership, no date, 2016 Action Agenda Update: LIO Planning, http://www.psp.wa.gov/2016 AA LIO planning.php, accessed March 8, 2016.

Ravetz, J.R., and S.O. Funtowicz. 1998. “Commentary.” Journal of Risk Research 1: 45-8.

Robinson, Cathy J., Richard D. Margerum, Tomas M. Koontz, Cassandra Moseley, and Sue Lurie. 2011. "Policy-level collaboratives for environmental management at the regional scale: Lessons and challenges from Australia and the United States." Society and Natural Resources 24:849-859.

Steelman, Toddi A., and JoAnn Carmin. 2002. "Community based watershed remediation: Connecting organizational resources to social and substantive outcomes." In Toxic Waste and Environmental Policy in the 21 st Century United States, edited by Diane Rahm. Jefferson, NC: McFarland Publishers.

Thomas, Craig W. 2003. Bureaucratic landscapes: Interagency cooperation and the preservation of biodiversity. Cambridge, MA: MIT Press.

United States Environmental Protection Agency (USEPA). 2009. "Technical tools for watershed management." http://www.epa.gov/owow/watershed/tools/ accessed 7/21/09. 
Weible, Christopher M. 2008. “A Collective Interest Model approach to explain the benefit-cost expectations of participating in a collaborative institution." Environment and Behavior 40(1): 2445.

Wondolleck, Julia M. and Steven L. Yaffee. 2000. Making collaboration work: Lessons from innovation in natural resource management. Washington, DC: Island Press.

Wynne, B. 1996. "May the sheep safely graze? A reflexive view of the expert-lay knowledge divide." In Risk, environment \& modernity. Towards a new ecology, ed. S. Lash, B. Szerszynski, and B. Wynne, 44-83. London: Sage. 